\title{
Satovakuutusten hinnoittelu ja maatilojen riskiluokittelu
}

\author{
Sami Myyrä ${ }^{1)}$ ja Kyösti Pietola ${ }^{2)}$ \\ ${ }^{1)}$ MTT taloustutkimus, Latokartanonkaari 9, sami.myyra@mtt.fi \\ ${ }^{2)}$ MTT taloustutkimus, Latokartanonkaari 9, kyosti.pietola@mtt.fi
}

\section{Tiivistelmä}

Tässä tutkimuksessa tutkittiin moraalikadon esiintymistä suomalaisessa satovahinkojärjestelmässä. Suomalainen satovahinkojärjestelmä on verrattavissa maailmalla hyvinkin yleisiin kaupallisiin satovahinkotuotteisiin. Keskeisenä erona on kuitenkin se, että satovahinkojärjestelmä on julkisesti rahoitettu ja avoin kaikille järjestelmän piiriin kuuluvia kasveja viljeleville. Siksi satovahinkoaineistossa ei esiinny käänteistä valintaongelmaa ja tutkimuksessa voidaan keskittyä muiden epäsymmetrisestä informaatiosta johtuvien ongelmien tarkasteluun. Nämä ominaisuudet tekevät satovahinkojärjestelmän korvausaineistosta aivan ainutlaatuisen ja tärkeän tutkimuskohteen. Tulokset auttavat uusien kaupallisten sovellutusten kehitystyössä ja luovat siten pohjaa markkinalähtöisten riskinhallintamekanismien muodostumiselle.

Tulosten perusteella $60 \%$ maatiloista ei ole saanut satovahinkokorvausta viimeisen 15 vuoden aikana. Näiden tilojen tulisikin kuulua kaupallisten satovahinkosovellutusten hinnoittelussa kaikkein edullisimpaan hintaryhmään, jos kaikille tiloille sovelletaan samaa alueellista viitesatoa myös kaupallisissa tuotteissa samaan tapaan kuin nykyisessä satovahinkojärjestelmässä. Ne tilat, jotka ovat satovahinkokorvauksia saaneet, saivat niitä tyypillisesti kerran tai kaksi. Aineisto osoitti kuitenkin sen, että pienellä osalla tiloista tapahtui satovahinkoja ja ne saivat satovahinkokorvauksia useammin kuin voidaan olettaa tapahtuvan satotilastojen perusteella. Satovahinkojen suhteen korkean riskin tiloilla riskin tulisi vaikuttaa myös satovahinkovakuutuksen hintaan.

Vahvaa näyttöä saatiin siitä, että tilan alhainen keskimääräinen satotaso selittää satovahinkojärjestelmän määritelmän mukaisten satovahinkojen yleisyyttä. Alhaisen satotason tilojen vakuutusturva satovahinkojen varalle on nykyisessä valtion ylläpitämässä ja kaikille avoimessa satovahinkojärjestelmässä huomattavasti parempi kuin korkean satotason tilojen. Lisäksi nykyinen satovahinkojärjestelmä ohjaa satovahinkojärjestelmän kautta tukirahoja alhaisen satotason tilalle ja hidastaa siten osaltaan maatalouden tuottavuuskehitystä. Keskimääräinen tilakohtainen satotaso ei kuitenkaan ole kaupallisia satovahinkovakuutuksia myyvien vakuutusyhtiöiden tiedossa. Tämä epäsymmetrinen informaatio saattaa estää kaupallisten satovahinkovakuutusmarkkinoiden synnyn.

Logit-mallinnuksella voitiin osoittaa joitain tilakohtaisia ja havaittavissa olevia tekijöitä, joita voidaan käyttää indikaattoreina satovahinkojen esiintymistä ennakoitaessa. Näitä tekijöitä voidaan käyttää maatilojen luokittelussa satoriskien suhteen. Riskiluokittelu on olennaisen tärkeä kaupallisten satovahinkotuotteiden hinnoittelussa. Vastaavia mekanismeja käytetään yleisesti vakuutusten hinnoittelussa. Hyvä esimerkki tästä ovat autojen liikennevakuutukset.

Asiasanat Satovakuutus, moraalikato, käänteinen valintaongelma 


\section{Johdanto}

Perinteisissä satovahinkovakuutuksissa korvaukset ovat perustuneet toteutuneen tilakohtaisen sadon ja viitesadon eroon. Viitesato on johdettu joko tilakohtaisesta tai alueellisesta satohistoriasta. Aikaisempi kirjallisuus osoittaa, että satovakuutuksissa sekä toteutuneet satovahingot että niistä seuraavat satovahinkokorvaukset ovat olleet osittain endogeenisia (Just et al. 1999). Tämä johtuu siitä, että vakuutetut viljelijät ovat voineet muuttaa viljelymenetelmiään satovakuutuksen ottamisen jälkeen, eikä satovahinkovakuutuksen alainen viljely vastaa vakuutusta edeltänyttä vakuuttamatonta viljelyä. Näitä viljelymenetelmien muutoksia voivat olla esimerkiksi satovarmuutta lisäävien panosten kuten kasvinsuojeluaineiden, kastelujärjestelmien, peruskuivatusjärjestelmien tai perusparannusten käytön laiminlyönnit (Chambers 1989, Smith ja Goodwin 2006). Tämä ns. moraalikato-ongelmaa, voi tehdä satoriskeistä vakuutustuotteiksi sopimattomia ja siten hajottaa koko satovahinkovakuutus järjestelmän. Tässä tutkimuksessa selvitettiin, esiintyykö moraalikato-ongelmaa suomessa toteutetussa satovahinkojärjestelmässä.

Satovahinkovakuutuksille on vahva poliittinen tuki. Satovahinkovakuutukset ovatkin olleet tyypillisesti vahvasti tuettuja. Esimerkiksi Euroopassa CAP uudistus mahdollistaa 65 \% vakuutusmaksutuen yleisille vakuutusyhtiöiden myymille satovakuutuksille. Nämä vakuutusyhtiöiden myymät satovahinkotuotteet ovat korvaamassa aikaisempia kansallisesti toteutettuja satovahinko sovellutuksia. Esimerkiksi Suomessa vuosittaisilla poikkeusluvilla sovellettu satovahinkojärjestelmä on nyt poistumassa. Suomessa satovahinkojärjestelmä on ollut 100 prosenttisesti valtion ylläpitämä.

Suomessa toteutettu, ja vielä vuonna 2013 sovellettava satovahinkojärjestelmä antaa suojan kaikkia sääilmiöitä vastaa, sillä vakuutus perustuu toteutuneeseen satoon. Järjestelmä on myös avoin kaikille yleisimpiä viljelykasveja viljeleville viljelijöille. Satovahinkojärjestelmä ei kärsi vapaaehtoisten vakuutusten tapaan vakuutuksen ottajien haitallisesta valikoitumisesta. Satovahinkojärjestelmän tuottama aineisto toteutuneista satovahingoista antaakin ainutlaatuisen mahdollisuuden tarkastella epäsymmetriseen informaatioon liittyviä ongelmia. Tarkastelun kohteena on erityisesti se, että tapahtuuko satovahinko useammin joillain tietyntyyppisillä tiloilla.

\section{Aineisto ja menetelmät}

Suomalaisen satovahinkovakuutusjärjestelmän peruspiirteet vastaavat tavanomaisia satoindekseihin perustuvia kaupallisia satovahinkovakuutustuotteita. Satovahinkovakuutusjärjestelmässä viljelijä on oikeutettu satovahinkokorvaukseen, jos tilan kohtaama satovahinko on suurempi kuin 30 prosentin omavastuu. Suomalaisessa satovahinkovakuutusjärjestelmässä korvaukset perustuvat maakuntakohtaisiin normisatoihin. Tilakohtaisen hakemuksen ja vahinkotarkastuksen perusteella toteutunutta satotasoa verrataan maakunnan normisatoon satovahingon toteutumista ja suuruutta arvioitaessa. Satovahinkovakuutusjärjestelmä kattaa satovahingot omavastuun jälkeen 100 prosenttisesti. Omavastuun ylittäneen satovahingon arvo lasketaan käyvien markkinahintojen avulla. Laatutappioiden osalta satovahinkokorvaus on kuitenkin 0 prosenttia, sillä satovahinkovakuutus korvaa vain sadon määrälliset tappiot, ei laadullisia. Naiden ominaisuuksien perusteella todellinen satovahinkosuoja on alempi korkean tuottavuuden (korkeampi keskisato ja keskimääräistä parempi laatu) tiloille kuin matalan tuottavuuden tiloille (Kuva 1). 


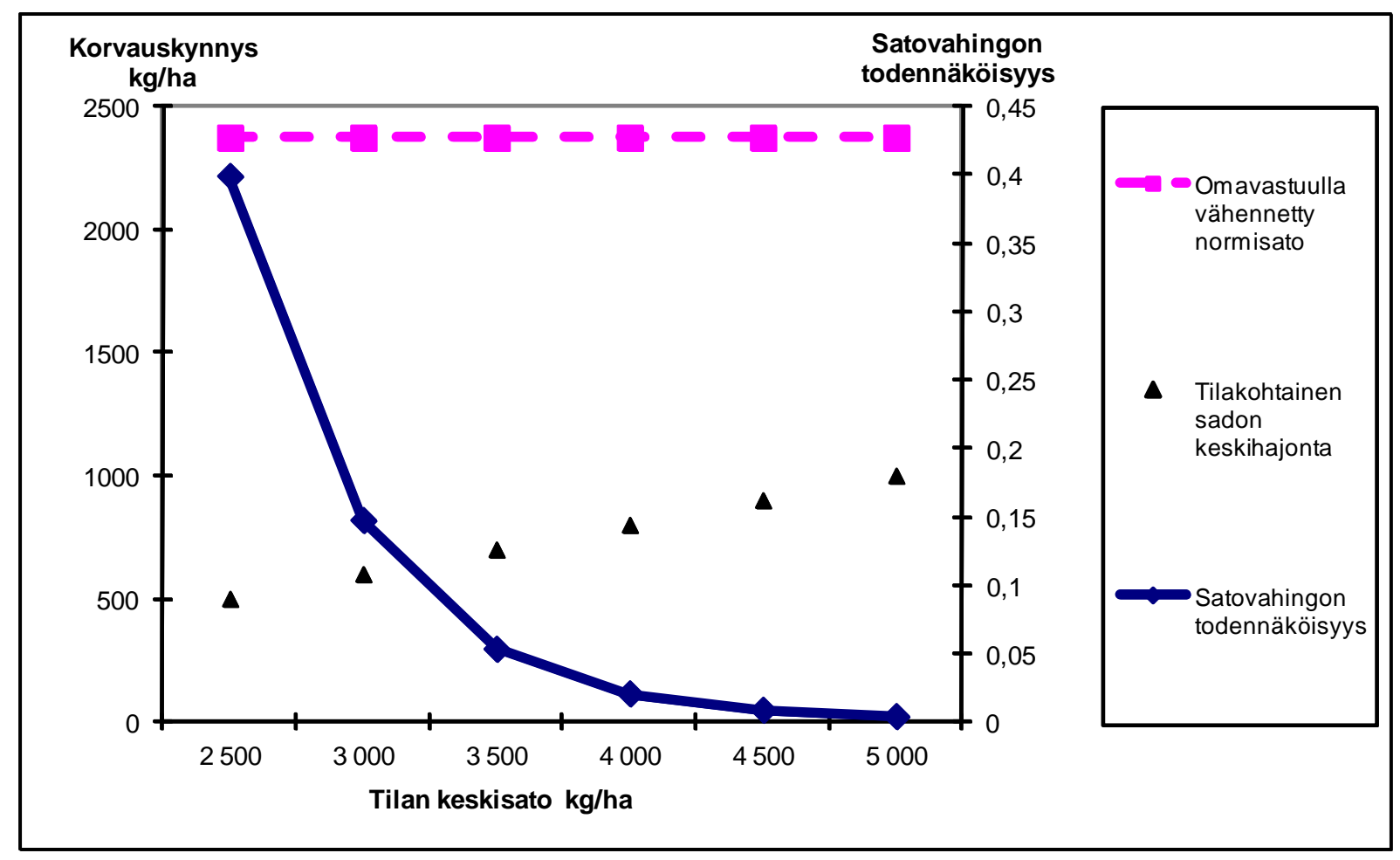

Kuva 1. Tilan keskimääräisen satotason (x-akseli) ja sadon keskihajonnan (pisteet) vaikutus satovahingon todennäköisyyteen (tumma alas laskeva käyrä). Normisatona on käytetty syysvehnän keskisatoa vuosina 19802009 (3 388 kg/ha). Vakuutuskorvauksen kynnysarvo on (3 388 kg/ha*0,7= 2372 kg/ha).

Kuva 1 on esimerkki tilakohtaisen keskisadon vaikutuksesta satovahingon todennäköisyyteen. Esimerkkilaskelma perustuu oletukseen, että satojakauma noudattelee normaalijakaumaa. Keskihajonta on vakioitu kaikille satotasoille niin, että se on $20 \%$ keskisadosta. Esimerkkilaskelmassa matalalla satotasolla (2 $500 \mathrm{~kg} / \mathrm{ha}$ ) toimivan tilan satovaihtelu + / - yhdellä keskihajonnalla (500 kg/ha) on 2000 - $3000 \mathrm{~kg} / \mathrm{ha}$. Esimerkkinä käytettävän satovahinkovakuutuksen korvauskynnys $2372 \mathrm{~kg} / \mathrm{ha}$ on aivan tavanomainen satotaso alhaisen keskisadon tilalle. Käyttäen hyväksi normaalijakauman kertymäfunktiota voidaan arvioida, että matalan satotason tila kohtaa satovahingon neljänä vuonna kymmenestä. Korkean satotason tilalla (5 $000 \mathrm{~kg} / \mathrm{ha}$ ) sadon normaali vaihteluväli arvioituna $20 \%$ keskihajonnalla on $4000-6000 \mathrm{~kg} / \mathrm{ha}$. Satovahinkovakuutuksen korvauskynnyksen $2373 \mathrm{~kg} / \mathrm{ha}$ mukainen sato on korkean satotason tilalla erittäin epätodennäköinen. Korkean satotason tilalla saadaan näin huono sato kerran 250 vuodessa. Esimerkkilaskelma osoittaa, että korkean satotason tila ei saa nykyisen kaltaisesta satovahinkovakuutuksesta käytännössä minkäänlaista suojaa oman satotasonsa vaihtelun varalle. Satovahinkovakuutusjärjestelmän ollessa avoin (ilmainen) kaikille viljelijöille ei järjestelmän tiloja eriarvoisesti kohteleva luonne tule helposti esiin. Viljelijät eivät valikoidu vakuutusyhtiön tiskille kaikkien saadessa vakuutusturvan satovahingon varalle automaattisesti.

Satovahinkojärjestelmän arvo erilaisilla satotasoilla toimiville tiloille voidaan laskea (Kuva 2). Lähtötietoina voidaan käyttää edellä kuvattua satovahingon todennäköisyyttä sekä viljan markkinahintaa (tässä esimerkissä $150 € /$ ). Lisäksi oletetaan, että 50 \% vakuutuskynnyksen alittavasta sadosta on tuhoutunut. Näillä oletuksilla matalan satotason (2 $500 \mathrm{~kg} / \mathrm{ha}$ ) tilan kannattaisi maksaa nykyisen kaltaisesta satovahinkovakuutuksesta $71 € /$ ha. Korkean satotason tilan ei puolestaan kannata maksaa samoilla ehdoilla toteutetusta satovahinkovakuutuksesta kuin $1 € /$ ha.

Tilakohtaiset keskisadot ovat vain viljelijöiden tiedossa. Tästä epäsymmetrisestä informaatiosta johtuen yksityisten finanssitavaratalojen on lähes mahdotonta hinnoitella vakuutuksia tilakohtaisesti. Tätä ilmiötä pidetäänkin yhtenä keskeisimmistä syistä siihen, miksi kaupalliset satovahinkotuotteet eivät ole yleistyneet. Tässä tutkimuksessa mallinnettiin toteutuneiden satovahinkokorvausten tilakohtaiseen yleisyyteen, eli satovahinkojen todennäköisyyteen vaikuttavia tilakohtaisia ja havaittavissa olevia ominaispiirteitä. 


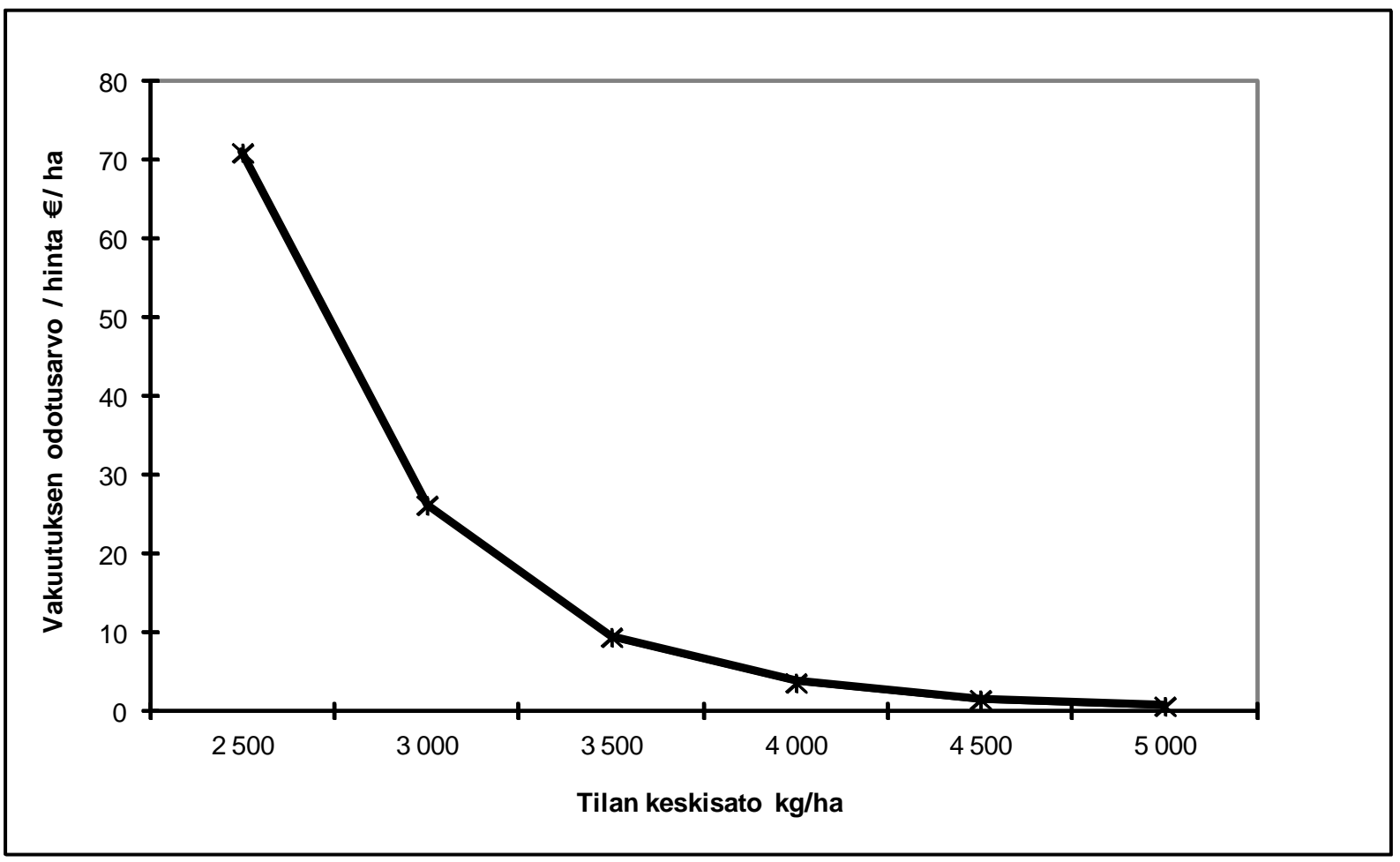

Kuva 2. Paljonko eri satotasoilla toimivien tilojen kannattaa maksaa (= vakuutuksen odotusarvo) nykyisen kaltaisesta satovahinkovakuutuksesta.

Logit malleja käytettiin tarkasteltaessa mitkä tilakohtaiset tekijät parhaiten selittävät havaittuja satovahinkoja. Ensimmäisessä mallissa selitettävä muuttuja sai arvon 1 jos tilalla oli sattunut satovahinkokorvaukseen oikeuttava satovahinko vähintään kerran viimeisen viidentoista vuoden aikana. Jos yhtään satovahinkoa ei ollut sattunut, muuttujan arvo oli 0. Logit malli on muotoa:

$P($ loss $)=\frac{e^{\beta^{\prime} x}}{1+e^{\beta^{\prime} x}}$

missä $\mathrm{P}($ loss) on logit function kertymäfunktio, $\beta$ on estimoitavien parametrien vektori ja $\mathrm{x}$ on selittävien muuttujien vektori. Analyysi aloitettiin regressioanalyysillä, jossa tilakohtaista satovahinkojen määrää (vuosia) viimeisen viidentoista vuoden aikana selitettiin tilakohtaisilla tekijöillä. Seuraavaksi aineistoon sovitettiin edellä kuvattua standardi logit malli. Lopuksi testattiin ordered logit mallilla voisiko mallin toimivuutta parantaa huomioimalla satovahinkojen useuden viimeisen viidentoista vuoden.

Aineisto on yhdistelmä havaittujen satovahinkojen määrästä ja tilakohtaisista tiedoista. Satovahinko aineisto on täydennetty niiden tilojen tiedoilla, jotka eivät ole vuosina 1995-2010 kertaakaan hakeneet satovahinkokorvauksia (0 tilat). Tilakohtaiset tiedot kaikista suomen maatiloista on poimittu vuoden 2005 poikkileikkausaineistosta. Aineistosta havaittu tilakohtainen satovahinkojen useus vuosina 1995-2010 on esitetty taulukossa 1.

Vuonna 1995 suomessa oli 95562 maatilaa ja maatilojen määrä laski 63716 maatilaan vuonna 2010. Vuosien 1995-2010 aikana 40267 maatilaa haki satovahinkokorvauksia vähintään kerran. Keskimäärin joka neljäs hakemus hylättiin. Vähintään kerran satovahinkokorvauksen saaneita tiloja aineistossa oli yhteensä 29 073. Suurin osa tiloista sai satovahinkokorvauksen vain kerran (19 506 tilaa). Joka viides vuosi (3 satovahinkokorvausta vuosina 1995-2010) satovahinkokorvauksen on saanut 2057 tilaa (Taulukko1). 
Taulukko 1. Poikkileikkausaineisto suomalaisista maatiloista vuonna 2005, vuosina 1995-2010 sattuneiden satovahinkojen mukaan.

\begin{tabular}{cr}
$\begin{array}{c}\text { Satovahinkokorvausten } \\
\text { lukumäärä }\end{array}$ & $\begin{array}{l}\text { Tilojen } \\
\text { lukumäärä }\end{array}$ \\
\hline 0 & 45784 \\
1 & 19506 \\
2 & 6300 \\
3 & 2057 \\
4 & 700 \\
5 & 292 \\
6 & 109 \\
7 & 51 \\
8 & 32 \\
9 & 14 \\
10 & 5 \\
11 & 5 \\
12 & 1 \\
13 & 1 \\
14 & 0 \\
15 & 0 \\
\hline
\end{tabular}

Satovahinkojen useutta selittävien muuttujien valinnassa kiinnitettiin huomiota siihen, että ne ovat helposti tilalla havaittavissa. Aikaisemmasta kirjallisuudesta poimittiin myös selittäviä muuttujia, joilla on pystytty järjestämään tiloja satovahingon todennäköisyyden suhteen (Smith ja Baquet 1996; Coble et al. 1996; Misha and Goodwin 2006).

\section{Tulokset}

Käytetyissä malleissa selitettävää muuttujaa (satovahinkojen määrää vuosina 1995-2010) käsitellään eri tavoin. Lineaarisessa regressiomallissa selitettävää muuttujaa käytetään jatkuvan muuttujan tapaan (min 0, max 15). Logit mallissa selitettävä muuttuja voi saada vain arvoja 1 ja 0 riippuen siitä onko tila saanut yhtenäkään vuonna satovahinkokorvausta. Ordered logit mallissa sallitaan selitettävälle muuttujalle (satovahinkojen määrälle vuosina 1995-2010) useampi arvo kuin logit mallissa käytetyt 1 ja 0 . Mallien erilaisuudesta huolimatta ne antavat hyvin samansuuntaisia tuloksia (Taulukko 2). Mallien tuloksia tarkastellaankin yhtenä kokonaisuutena.

Mallien tulosten perusteella satovahingon todennäköisyys on suurempi Etelä- ja Länsi-Suomessa kuin Pohjois- ja Itäsuomessa. Tämä suuntaus on selkeä vaikka kuntakohtaiset tekijät on huomioitu. Nämä kompassisuuntiin sidotut efektit erottuvat selvästi kun aineisto tulostetaan kartalle. Tämä tulos on hieman yllättävä ainakin sääolosuhteita vasten tarkasteltuna. Looginen selitys löytyy kuitenkin alueellisista kasvilajivalikoimista. Pohjois- ja Itä-Suomessa suurempi osa peltoalasta on allokoitu nurmelle ja pienempi osa viljakasveille kuin Etelä- ja Länsi-Suomessa. Pellonkäyttövalintojen vaikutusta tukee myös se, että tilalla olevien märehtijöiden määrä alentaa satovahinkokorvaukseen johtavan satovahingon todennäköisyyttä. Tämä siitä huolimatta, että kuivaheinälle, säilörehunurmelle, tuorerehulle ja laitumelle on määritetty yhtäläiset perusteet (normisadot) satovahingon toteamiseksi kuin viljakasveille.

Isommat tilat ovat kohdanneet enemmän satovahinkoja, jotka ovat johtaneet satovahinkokorvaukseen kuin pienet tilat. Tulos on hieman yllättävä, sillä satovahinkojärjestelmän pitäisi olla tilakoon suhteen neutraali. Ilmeisesti satovahinkokorvausten hakemiseen liittyy kuitenkin kustannuksia, joista johtuen aivan pienimpiä odotettavissa olevia satovahinkokorvauksia ei edes haeta. Tulos tukee käsitystä jonka mukaan satovahinkojen tilakohtaisesta tarkastamisesta aiheutuu huomattavia kustannuksia. 
Yhteiskunnan näkökulmasta nämä kustannukset jäävät usein näkymättömiksi, vaikka yhteenlaskettuna ne voivat kaataa koko järjestelmän kaupalliset mahdollisuudet.

Oman pellon suhteellisella osuudella ei ollut yhteyttä satovahinkoihin. Malli ei siis anna tukea yleiselle oletukselle pellon hallintaoikeuden epävarmuuden yhteydestä perusparannuksiin ja siten myös satovahinkoihin. Tulos ei kuitenkaan sulje pois sitä vaihtoehtoa, ettei satovahinko voisi sattua useammin vuokrapellolla kuin viljelijän omalla pellolla. Rakennekehityksen myötä parhaat ja korkeimman tuottavuuden viljelijät ovat olleet niitä, jotka ovat nopeimmin voineet laajentaa tuotantoaan. Tilakoon kasvu on perustunut pääsääntöisesti pellon vuokraukseen. Oman pellon suhteellista osuutta kuvaavassa muuttujassa on siis samanaikaisesti näkyvissä tuottavimpien viljelijöiden ja pellonvuokrauksen vaikutus. Looginen tulos onkin, ettei oman pellon suhteellinen osuus selitä sattuneita satovahinkoja.

Taulukko 1. Estimoidut mallit.

\begin{tabular}{|c|c|c|c|c|c|c|}
\hline Parametriestimaatit & $\begin{array}{l}\text { Lineaarinen } \\
\text { regressiomalli }\end{array}$ & $\begin{array}{l}\operatorname{Pr}> \\
|t|\end{array}$ & Logit & $\begin{array}{l}\operatorname{Pr}> \\
\text { ChiSq }\end{array}$ & $\begin{array}{l}\text { Ordered } \\
\text { logit }\end{array}$ & $\begin{array}{l}\mathrm{Pr}> \\
\text { ChiSq }\end{array}$ \\
\hline vakio12 & & & & & 13.3543 & $* * *$ \\
\hline vakio 10 & & & & & 14.4535 & $* * *$ \\
\hline vakio 9 & & & & & 14.7415 & $* * *$ \\
\hline vakio 8 & & & & & 15.4354 & $* * *$ \\
\hline vakio 7 & & & & & 15.6591 & $* * *$ \\
\hline vakio 6 & & & & & 16.1306 & $* * *$ \\
\hline vakio 5 & & & & & 16.8265 & $* * *$ \\
\hline vakio 4 & & & & & 17.9243 & $* * *$ \\
\hline vakio 3 & & & & & 18.9486 & $* * *$ \\
\hline vakio 2 & & & & & 20.455 & $* * *$ \\
\hline vakio 1 & 5.80118 & $* * *$ & 21.4676 & $* * *$ & 22.1251 & $* * *$ \\
\hline kompassisuunta pohjoinen & -0.00038 & $* * *$ & -0.00125 & $* * *$ & -0.00135 & $* * *$ \\
\hline kompassisuunta itä & -0.00089 & $* * *$ & -0.00426 & $* * *$ & -0.00423 & $* * *$ \\
\hline $\begin{array}{l}\text { tilakoko } \\
\text { oman pellon suhteellinen }\end{array}$ & 0.00432 & $* * *$ & 0.011 & $* * *$ & 0.011 & $* * *$ \\
\hline osuus & 0.000711 & & 0.00912 & & 0.0013 & \\
\hline nautoja & -0.00369 & $* * *$ & -0.00742 & $* * *$ & -0.00858 & $* * *$ \\
\hline sikoja & 0.00117 & $* * *$ & 0.00452 & $* * *$ & 0.00293 & $* * *$ \\
\hline hevosia & -0.00042 & & -0.00495 & & -0.005 & \\
\hline siipikarjaa & 1.89E-05 & & -0.00496 & $* * *$ & -0.00378 & $* * *$ \\
\hline lampaita & -0.00818 & $* * *$ & -0.0177 & $*$ & -0.0179 & $* *$ \\
\hline viljelijän ikä & 0.00245 & $* * *$ & 0.00599 & $* * *$ & 0.00638 & $* * *$ \\
\hline \multicolumn{7}{|c|}{$\begin{array}{l}\text { Kotieläinlajit on tehty vertailukelpoisiksi käyttämällä eläin yksiköitä. } \\
\text { Havainnot satovahinkojen lukumääristä } 11 \text { ja } 13 \text { puuttuvat, sillä aineistoa on supistettu viljelijän ikää koskevien } \\
\text { puuttuvien havaintojen osalta. satovahinkojen lukumäärät } 14 \text { ja } 15 \text { eivät esiinny aineistossa. } \\
\operatorname{Pr}<0.01^{* * *},<0.05^{* *} \text { and }<0.1^{*}\end{array}$} \\
\hline
\end{tabular}

Tilalla olevien eläinten lukumäärä alensi satovahingon todennäköisyyttä yleensä. Eri eläinlajien välillä on kuitenkin huomattavia eroja. Säilörehun viljelyyn erikoistuneet tilat (tilalla lehmiä, lampaita tai hevosia) kohtasivat harvemmin satovahinkoja kuin viljatilat ja sikatilat. Tähän voi olla syynä esimerkiksi se, että harvaan asutuilla maatalousalueilla viljelijät panostavat karkearehujen viljelyyn enemmän taatakseen tilakohtaisen omavaraisuuden karkearehujen suhteen. Karkearehujen viljelyssä sattuvaa satovahinkoa voi olla vaikea korvata rahalla, sillä markkinoilta ei ehkä löydy karkearehuille täydennystä tai korviketta. Voi olla myös niin, että karkearehujen viljelyssä sattuneen satovahingon todentaminen on koettu hankalammaksi kuin viljanviljelyssä sattuneen satovahingon todentaminen.

Viljelijän ikä oli mallinnuksen kannalta kriittinen tekijä, sillä viljelijän ikä puuttui aineistosta usealta tilalta. Estimointitulokset eivät kuitenkaan muuttuneet suuresti, vaikka viljelijän ikä otettiin malliin ja samalla tiputettiin aineistosta pois ne tilat joilta viljelijän ikä puuttui. Aineisto antoi vahvan tuen sille, että viljelijän iän ja satovahingon todennäköisyyden välillä on positiivinen korrelaatio.

Aineistosta tarkasteltiin myös kuntakohtaisia eroja. Mallissa selvitettyjä kuntakohtaisia eroja ei 
kuitenkaan esitetty taulukossa 2. Kuntakohtaiset erot (fixed effects) olivat pääsääntöisesti tilastollisesti merkitseviä. Käytännössä tämä tarkoittaa sitä, että satovahinkovakuutuksen ehtojen ja toteutuneen satovahingon arvioinnissa on kuntakohtaisia eroja. Tilakohtainen satovahinkojen arviointi on tulosten perusteella kallista, eivätkä kaikki vakuutetut saa samaa kohtelua.

\section{Johtopäätökset}

Vakuutustuotteiden tuotekehittelyssä ja hinnoittelussa tilakohtaisten helposti havaittavissa olevien muuttujien kytkeminen satovahinkoihin on äärimmäisen tärkeää. Tämä erityisesti siksi, että tilakohtaisista satojakaumista ei ole tietoa kenelläkään muulla kuin viljelijällä itsellään. Tämän tutkimuksen tavoitteena oli etsiä niitä tilakohtaisia tekijöitä, jotka selittävät toteutuneita tilakohtaisia satovahinkoja ja auttaa siten satovahinkovakuutusten tarjoajia ja maatalouspolitiikan tekijöitä tuottamaan tehokkaampia tuotteita viljelijöiden satoriskien hallintaan.

Tulosten perusteella suurin osa tiloista (60 \%) ei ole kohdannut $30 \%$ omavastuun ylittävää satovahinkoa viimeisen viidentoista vuoden aikana. Ne tilat jotka ovat satovahinkokorvauksia hakeneet, ovat tyypillisesti hakeneet korvauksia kerran tai kahdesti vuosina 1995-2010. Osa viljelijöistä on kuitenkin hakenut ja myös saanut satovahinkokorvauksia huomattavasti useammin kuin mitä voidaan arvioida todennäköiseksi koko maan satotilastojen perusteella.

Käytetyillä malleilla voitiin kytkeä joitain tilakohtaisia tekijöitä satovahingon todennäköisyyteen. Esimerkiksi intensiivinen kotieläintuotanto antaa viljelijälle kannusteita hyvään karkearehujen satotasoon pyrkimiseen kaikissa sääolosuhteissa. Toisaalta viljelijän iällä näyttää olevan selvä positiivinen yhteys satovahingon todennäköisyyteen. Tulosten perusteella saatiin myös näyttöä siitä, että satovahinkojen tilakohtainen arviointi on kallista, eikä silti johda vakuutettujen yhtenäiseen kohteluun.

\section{Kirjallisuus}

Coble, K., Knight, T., Pope, R. and Williams, J. 1996. Modelling Farm-Level Crop Insurance Demand with Panel Data. American Journal of Agricultural Economics 78:439-447.

Chambers, R. 1989. Insurability and Moral Hazard in Agricultural Insurance Markets. American Journal of Agricultural Economics 71:604-616.

Just, R., Calvin, L. and Quiggin, J. 1999. Adverse Selection in Crop Insurance: Actuarial and Asymmetric Information Incentives. American Journal of Agricultural Economics 81:834-849.

Mishra, A. and Goodwin, B. 2006. Revenue insurance purchase decisions of farmers. Applied Economics. 38:149-159.

Smith, V. and Baquet. 1996. The Demand for Multiple Peril Crop Insurance: Evidence for Montana Wheat Farmers. American Journal of Agricultural Economics 78:189-201.

Smith, V. and Goodwin, B. 1996. Crop insurance, Moral Hazard, and Agricultural chemical Use. American Journal of Agricultural Economics 78:428-438. 